\title{
Methods for and pigments extration and determination of color in tomato for processing cultivars
}

\author{
Darlene Ana de Paula VIEIRA ${ }^{1}$, Márcio CALIARI ${ }^{1 *}$, Eli Regina Barboza de SOUZA ${ }^{1}$, \\ Manoel Soares SOARES JÚNIOR ${ }^{1}$
}

\begin{abstract}
The aim of this research was compare methods for pigments extraction and color determination in different tomato for processing cultivars, and choose the most promising materials for the industry. The tomatoes for processing studied were of the IT761, H9992, H9553, AP533, Advance, N901, BRSena, U2006, HY26, HY37 and HY68 cultivars. The extraction yields of lycopene and $\beta$-carotene using acetone and the mixture of ethanol, acetone and hexane (10:10:20) were determined, and the parameters of color were determined by colorimetric and digitals image methods (Cielab and Hunterlab), besides other physicochemical characteristics. The mixture of solvents is more efficient in the extraction of lycopene and $\beta$-carotene than acetone on its own. The methods of assessing the color through image presented higher levels of luminosity and chrome $\mathrm{a}^{*}$ and $\mathrm{b}^{*}$ than the instrumental method, given that the Hunterlab is closer to the colorimeter method, than Cielab. The analysis through digital images indicates that the procedure is promising, and it can be used as a instrument for analysing tomato colors. Considering that the level of TSS is fundamental to industrial performance, the IT761, BRSena, AP543, and H9992 cultivars stand out, moreover these cultivars have higher levels of lycopene and darker red color.
\end{abstract}

Keywords: lycopene; $\beta$-carotene; colorimetry; digital image; total soluble solids.

Practical Applications: The solvent mixture showed to be more effective than by only acetone. The color determination by digital images methods indicated that the procedure is promising. The IT761, BRSena, AP533 and H9992 cultivars t are most desirable for the industry.

\section{Introdution}

Tomato for processing has not only its importance for produce, but has also a socio-economic value (Schwarz et al., 2013), its plantation has experienced a growth in its production area in the last few years, with a global production of 77 million tons of tomatoes in 2014 (The World Processing Tomato Council, 2015). The Brazil produced 1,9 million tons of tomatoes for processing in 2014 , a value which positioned the country as the seventh producer in the world. Of this total amount, Goiás produced 1,1 million tons, with the involvement of, approximately, $65 \%$ of all the tomato produce destined for industrial in Brazil (Revista Campo \& Negócios, 2014), the quality of the fruit is one of the most important aspects that is evaluated by the industries.

With an increasing consumer demand, the food industry has dismissed several efforts in order to measure and control the physical and chemical characteristics of its produce. The color is a key feature for foodstuffs, as its appearance allows the detection of imperfections and defects. In the food industries, the color of the Cielab system is easily measured by instrumental methods which utilise a colorimeter or a spectrophotometer (Wu \& Sun, 2013), which are high cost materials. Materials that are opaque, homogeneous or have a smooth surface, can be easily perceived by the naked eye. However, fleshy fruits are highly heterogeneous, as the surface, the texture, the glow and the shape have a substantial influence upon human perception (Van Dalen et al., 2010). However, there are other alternative techniques to determine color that are less costly, such as capturing images digitally.

Tomato has reached an enormous popularity in the last few years with the discovery of lycopene's antioxidant properties, as well as its anti-carcinogenic properties (Raiola et al., 2014; Wu et al., 2011). There is a general agreement within the scientific community that in order to obtain the maximum benefit and protection from natural antioxidants, our food intake must be as colorful as possible. Besides the nutraceutical properties of the lycopene, its concentration in tomatoes has a direct correlation to a better appearance of the product, which leads to a high demand for increased levels of this pigment in fruit, both for its use as a fresh product or for industrial processing (Schwarz et al., 2013).

Apart from its color and pigmentation, other physicochemical factors of quality control deserve to be highlighted in tomatoes destined for processing; these are: the total solid soluble, the $\mathrm{pH}$ and the total acidity, which influence industrial productivity by using less energy in the operations when processing, as well as its sterilisation and its pulp concentration (Monteiro et al., 2008). In this context, the aim of this research was compare methods for determination of color and for pigments extraction in fruits of different tomato for processing cultivars, and choose the most promising genetic materials for the industry. 


\section{Materials and methods}

\subsection{Material}

The fruits of industrial tomato cultivars (IT761, H9992, H9553, AP533, Advance, N901, BRSena, U2006, HY26, HY37 and HY68) used in this study were donated by Cargill Agrícola S.A., from the experimental farm, located in Hidrolândia, Goiás, Brazil.

\subsection{Harvesting, sample preparation and experimental design}

The fruits were sampled from the third and fourth positions of the plant and third cluster were used. Tree samples for each cultivar (with 10 fruits each sample) were evaluated in relation to pigment extraction methods, to color determination method and other physicochemical characteristics. Fruits were manually harvested from June to September 2013, packed in low density polyethylene (LDPE) bags, properly coded, and immediately transported to the Plant Products Processing Laboratory (School of Agronomy, Federal University of Goiás). Tomatoes were manually selected regarding appearance, lack of injuries, rots and degree of ripeness, regardless of size. Then fruits were washed to remove surface dirt, rinsed under running water, submerged for $20 \mathrm{~min}$ in sodium hypochlorite solution $150 \mathrm{mg} \mathrm{L}^{-1}$ and left to dry naturally on screen tray.

The experiment was completely randomized, with factorial design (2 pigment extraction methods $\mathrm{x} 11$ cultivars, or 3 color determination methods $x 11$ cultivars), with or without the use of factorial design (others physicochemical characteristics), and tree repetitions (samples). All the analysis was carried out in triplicate.

\subsection{Extraction of pigments}

For the extraction of lycopene and $\beta$-carotene, $1 \mathrm{~g}$ of liquidised pulp was added to the solvents $(10 \mathrm{~mL}$ of ethanol, $10 \mathrm{~mL}$ of acetone and $20 \mathrm{~mL}$ of hexane). The mixture was placed in a tube covered with silver foil and a lid, and stored in a refrigerator at $3{ }^{\circ} \mathrm{C}$, where it remained until full depigmentation. Then another $10 \mathrm{~mL}$ of ethanol, $10 \mathrm{~mL}$ of acetone and $20 \mathrm{~mL}$ of hexane were added; this was later filtered in Whatman filter paper number 8 , whereby $50 \mathrm{~mL}$ of distilled water was added for phase separation, and then the whole mixture was poured into a $150 \mathrm{~mL}$ test tube, discarding the previous fraction. The reading was carried out in the supernatant at $503 \mathrm{~nm}$ for the lycopene and $450 \mathrm{~nm}$ for the $\beta$-carotene. A second technique was applied for the extraction of pigment, in which the mixture of solvents was substituted with only acetone P. A. In both techniques, the equations to measure the level of $\beta$-carotene and lycopene were developed by Georgé et al. (2011), and the result was given in $\mu \mathrm{g} \mathrm{g}^{-1}$ (Equations 1 and 2, respectively). The analysis of the pigments was determined in triplicate.

$$
\begin{aligned}
& C_{\beta \text {-carotene }}=4.624 X A_{450}-3.091 X A_{503} \\
& C_{\text {Lycopene }}=3.956 X A_{450}-0.8061 X A_{503}
\end{aligned}
$$

In which: $C_{\beta \text {-caroten } \theta} C_{\text {Lycopene }}=$ Lycopene and $\beta$-carotene concentration in $\mu \mathrm{g} \mathrm{g}^{-1} ; A_{450}$ and $A_{503}=$ absorbance in the respective wavelengths.

\subsection{Color determination}

Three techniques were applied, in order to determine the parameters of image and instrumental color: instrumental, with the usage of a colorimeter (Color Quest II, Hunter Lab, Reston, Canada), two digital/computational techniques, combining with a digital camera, computer and softwares.

The reading of the fruit skin obtained through a colorimeter was carried out (in the upper and inferior extremities as well as the equatorial area) and then the average of these areas was calculated. The apparatus was calibrated with a standard white ceramic plaque, whereby: the luminosity $\left(\mathrm{L}^{*}\right)$ represents how light and dark is the sample, varying between 0 (black) and 100 (white). Higher luminosity values indicate whiter colors. The chrome $\mathrm{a}^{*}$ values (x-axis) vary from green $(-)$ to red $(+)$; and chrome $b^{*}$ values (y-axis) from blue (-) to yellow $(+)$, in compliance with the International Commission of L'Éclairage (International Commission on Illumination, 2014).

The color by image was obtained through a digital camera (Samsung WB1000, Manaus, Brazil), with 12,2 megapixels of resolution. The fruits were placed against a black surface; the pictures were taken soon after harvesting, and the sample preparation, under controlled lighting (Philips, white color, $20 \mathrm{~W}$ ) with a $45^{\circ}$ angle inclination, and illuminant D65, which corresponds to midday lighting. The camera lens was placed at a perpendicular angle to the fruit surface at a distance of $400 \mathrm{~mm}$ from the black surface (Figure 1). By the Microsoft Paint Program were selected in the central area of the digital image of the fruit approximately $5 \times 5 \mathrm{~cm}$, still in Paint, clicked on color picker and then edit colors, converting the photo fragment into average RGB values using pixel by pixel color reading. The RGB values (red, green and blue) were entered into the Easy RGB Program converting then to the CieLab and HunterLab scales, obtaining the luminosity, chrome $\mathrm{a}^{\star}$ and chrome $\mathrm{b}^{\star}$ values.

\subsection{Others physicochemical characteristics}

In order to determine the total acidity (TA), 1,0 g of raw pulp was homogenised in $50 \mathrm{~mL}$ of distilled water, in which three drops of phenolphthalein alcoholic solution were added; it titrated with $\mathrm{NaOH} 0,1 \mathrm{~mol} \mathrm{~L}^{-1}$ until obtaining the turning point (pinkish coloration), resulting in a concentration of citric acid

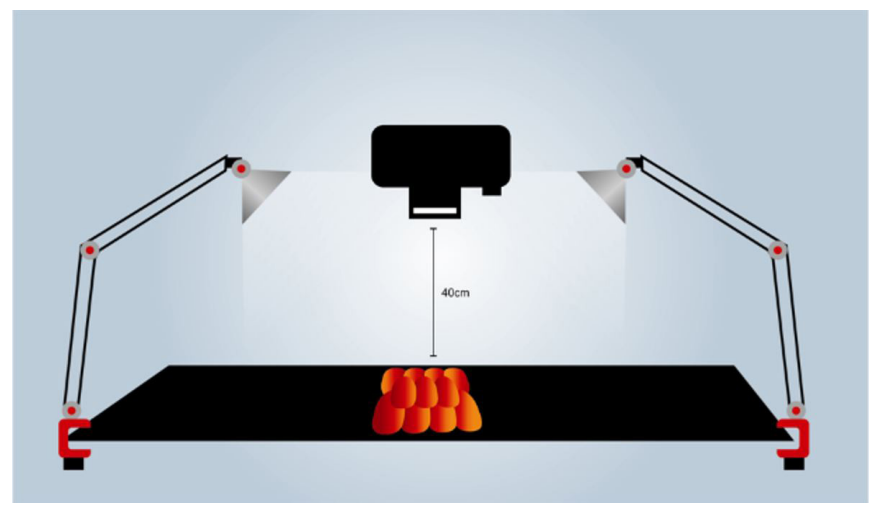

Figure 1. Layout of the digital image acquisition system for tomatoes (Solanum lycopersicum). 
$\left(\mathrm{g} 100 \mathrm{~g}^{-1}\right)$. For total solid soluble (TSS), approximately $5,0 \mathrm{~g}$ of raw homogenised pulp was macerated, and $50 \mu \mathrm{L}$ was transferred to the prism of the digital refractometer (Instruterm, RT-30 ATC, Sao Paulo Brazil). The ratio TSS/TA was also calculated. The $\mathrm{pH}$ was determined through $5,0 \mathrm{~g}$ of raw homogenised tomato pulp added to $50 \mathrm{~mL}$ of distilled water. The reading was carried out through a digital potentiometer calibrated with buffer solutions of $\mathrm{pH} 4$ and 7. All the physicochemical properties were determined with the recommended methodology by Association of Official Analytical Chemists (2012).

\subsection{Statistical analysis}

After normality and homogeneity tests, the data were submitted to analysis of variance (Anova), and the average was compared by test Turkey $(\mathrm{p}<0.05)$. The Pearson's correlation was established between the variables determined $(\mathrm{p}<0.05)$, and transformed mathematics were applied to color parameters. A free software Asssistant 7.7 Beta (UFCG, Campina Grande, Brazil).

\section{Results and discussions}

\subsection{Pigments}

The cultivar effect was significant for the lycopene and the $\beta$-carotene contents $(p<0.05)$. When the acetone was used on its own as an extractor solvent, the values for the lycopene amongst the cultivars ranged from 30.7 to $38.7 \mu \mathrm{g} \mathrm{g}^{-1}$, whilst the mixture of hexane, acetone and ethanol varied from 37.3 to $48.3 \mu \mathrm{g} \mathrm{g}^{-1}$ (Table 1). Schwarz et al. (2013) observed average contents of lycopene in tomatoes for processing between 16.1 and $72.1 \mu \mathrm{g} \mathrm{g}^{-1}$, and $38.7 \mathrm{e} 47.9 \mu \mathrm{g} \mathrm{g}^{-1}$, in the first and second year of cultivation, and of the ten cultivars analysed by them, the AP533 cultivar presented values between 38.9 and $42.6 \mu \mathrm{g}$ g- 1 of lycopene in the first and second year, respectively. In this research, it was found lower values for the same cultivar using extraction with acetone $\left(34.5 \mu \mathrm{g} \mathrm{g}^{-1}\right)$, and an intermediary level with the solvent mixture $\left(40.1 \mu \mathrm{g} \mathrm{g}^{-1}\right)$.
For the $\beta$-carotene extracted with acetone, its levels in the tomatoes were between 20.7 and $25.4 \mu \mathrm{g} \mathrm{g}^{-1}$ (22.7\%), and with the solvent mixture, it varied from 21.9 to $26.0 \mu \mathrm{g} \mathrm{g}^{-1}(18,7 \%)$ (Table 1). The highest level of $\beta$-carotene extracted with acetone was seen in fruits from the HY26 cultivar, followed by the HY68 and HY37 cultivars. The highest levels of $\beta$-carotene extracted with the solvent mixture were obtained from the BRSena, H9992, Advance, IT761, HY37 and N901 cultivars.

The highest yield of lycopene extraction with acetone was from the fruits of the N901 cultivar, followed by the H9553, H9992 and IT761 cultivars, whilst when extracting with the solvent mixture, it was obtained higher yield from the H9992 and IT761 cultivars, followed by the HY68, BRSena and HY37 cultivars (Table 1). According to Garcia \& Barrett (2006), the growing season, the plantation zone and the cultivar are important factors, as this may affect the concentration and pigmentation in tomatoes for processing.

When using the mixture of ethanol, acetone and hexane (1:1:2), the extraction either for the lycopene or the $\beta$-carotene, was higher in relation to the one with acetone on its own, with an exception to the $\beta$-carotene extraction of the HY26 and HY68 cultivars, because the interaction effect, method of extraction $x$ cultivar was very significant. According to Cruz et al. (2008), who performed the extraction of carotenoids from Bixa orellana $\mathrm{L}$., lower values were also determined when extracting with acetone.

According to Amr \& Hussein (2013), when combining the solvents for the extraction of carotenoids pigments, the efficiency was superior in comparison to the usage of solvents individually. Since, the polar solvents, such as ethanol and acetone, are able to enter phospholipidic substances which compose the cell lipoprotein membranes, whilst apolar solvents, such as hexane, are more efficient in solubilizing carotenoids. Lycopene and $\beta$-carotene are considered to be apolar substances. Therefore, the effect of polar and apolar solvent mixture in extracting pigments is higher than the effect of one single polar or apolar solvent, which leads to obtaining a better performance in extracting pigments, which also was observed in this study.

Table 1. Lycopene and $\beta$-carotene (average \pm average deviation) from ripe fruits of tomato for processing cultivars (Solanum lycopersicum), determined through of the methods of extraction with acetone and with mixture of ethanol, acetone and hexane (1:1:2). Goiânia, GO, Brazil.

\begin{tabular}{|c|c|c|c|c|}
\hline \multirow{2}{*}{ Cultivar } & \multicolumn{2}{|c|}{ Lycopene $^{(1)}$} & \multicolumn{2}{|c|}{$\beta$-carotene ${ }^{(1)}$} \\
\hline & (Acetone) & (Mixture) & (Acetone) & (Mixture) \\
\hline IT761 (2) & $37.0^{\mathrm{Bb}} \pm 001$ & $47.6^{\mathrm{Aa}} \pm 0.04$ & $21.6^{\mathrm{Bde}} \pm 0.01$ & $25.0^{\mathrm{Aab}} \pm 0.03$ \\
\hline H9992 & $37.4^{\mathrm{Bb}} \pm 0.04$ & $48.3^{\mathrm{Aa}} \pm 0.14$ & $22.9^{\mathrm{Bc}} \pm 0.05$ & $25.3^{\mathrm{Aab}} \pm 0.08$ \\
\hline H9553 & $37.5^{\mathrm{Bb}} \pm 0.03$ & $39.9^{\mathrm{Ae}} \pm 0.05$ & $22.1^{\mathrm{Bcd}} \pm 0.06$ & $23.6^{\mathrm{Abc}} \pm 0.08$ \\
\hline AP533 & $34.5^{\mathrm{Bd}} \pm 0.01$ & $40.1^{\mathrm{Ae}} \pm 0.16$ & $21.2^{\mathrm{Bef}} \pm 0.02$ & $23.7^{\mathrm{Abc}} \pm 0.19$ \\
\hline Advance & $34.0^{\text {Bde }} \pm 0.03$ & $42.0^{\mathrm{Ad}} \pm 0.08$ & $20.8^{\mathrm{Bef}} \pm 0.04$ & $25.2^{\mathrm{Aab}} \pm 0.17$ \\
\hline N901 & $38.7^{\mathrm{Ba}} \pm 0.02$ & $43.1^{\text {Acd }} \pm 0.15$ & $22.7^{\mathrm{Bc}} \pm 0.03$ & $24.8^{\mathrm{Aab}} \pm 0.03$ \\
\hline BRSena & $30.7^{\mathrm{Bf}} \pm 0.04$ & $44.6^{\mathrm{Abc}} \pm 0.18$ & $18.4^{\mathrm{Bg}} \pm 0.09$ & $26.0^{\mathrm{Aa}} \pm 0.22$ \\
\hline U2006 & $35.3^{\mathrm{BC}} \pm 0.01$ & $37.3^{\mathrm{Af}} \pm 0.09$ & $20.7^{\mathrm{Bf}} \pm 0.02$ & $23.8^{\mathrm{Abc}} \pm 0.14$ \\
\hline HY26 & $35.5^{\mathrm{Bc}} \pm 010$ & $43.0^{\mathrm{Acd}} \pm 0.06$ & $25.4^{\mathrm{Aa}} \pm 0.08$ & $23.9^{\mathrm{Bbc}} \pm 0.12$ \\
\hline HY37 & $35.4^{\mathrm{Bc}}+0.05$ & $44.0^{\mathrm{Abc}} \pm 0.06$ & $23.9^{\mathrm{Bb}} \pm 0.07$ & $24.9^{\mathrm{Aab}} \pm 0.08$ \\
\hline HY68 & $33.7^{\mathrm{Be}} \pm 0.05$ & $45.4^{\mathrm{Ab}} \pm 0.14$ & $24.4^{\mathrm{Ab}} \pm 0.06$ & $21.9^{\mathrm{Bc}} \pm 0.18$ \\
\hline $\mathrm{CV}^{(3)}$ & 1.2 & 2.6 & 2.5 & 5.6 \\
\hline
\end{tabular}

${ }^{(1)} \mu \mathrm{g} \mathrm{g}{ }^{-1} ;{ }^{(2)}$ Average followed by different lower case letters in the same column, and capitals letters on the same line for lycopene and $\beta$-carotene, differ between each other through the Turkey test $(\mathrm{p}<0.05) ;{ }^{(3)}$ Coefficient of variation (\%). 


\subsection{Color}

The values for luminosity, chrome $\mathrm{a}^{*}$ and chrome $\mathrm{b}^{\star}$ varied significantly between cultivars $(\mathrm{p}<0.05)$, regardless of the color determination method. The luminosity of the fruits through the colorimetric method varied from 33.4 to 37.2 (Table 2). The lower levels of luminosity (darker tomatoes) were verified in the AP533, HY37, H9553 and Advance cultivars, and the highest (lighter tomatoes) in the HY26, H9992 and U2006 cultivars.

Through the images, the lowest value of luminosity, 42.9 and 36.5 respectively for CieLab and HunterLab methods, were determined in the H9992 cultivar, and only was differed from the IT761, BRSena and HY37 cultivars (Table 2). Méndez et al. (2011) studying the skin color of different local Mexican tomato cultivars by colorimetric method, found values of luminosity between 36.5 and 40.7 , close to those determined by colorimetric and HunterLab image methods.

CieLab or HunterLab methods determined values for chrome $\mathrm{a}^{*}$ significantly higher in comparison to values of the colorimeteric method, showing a strong red chromaticity in color (Table 3).

Rotino et al. (2005), examining seedless ripe tomatoes that were genetically modified, reported values of chrome $a^{*}$ ranging between 34.0 and 36.5, higher to the levels found in this research by colorimetric method, possibly due to the genetically improvement of the cultivars analyzed, but lower to determined by image methods.

The highest values of chrome $\mathrm{a}^{*}$ from the fruits (more reddish) through CieLab and HunterLab image methods were found in the N901, HY26, IT761, Advance, AP533, U2006 and HY68 cultivars, between 51 and 65.4 and 45.1 and 60.5, respectively (Table 3). The N901 and IT761 cultivars also obtained high levels of lycopene (Table 1).

The chrome $b^{*}$ values of the fruit determined by colorimeter varied $34.7 \%$, between 19.0 and 25.6 (Table 4 ). The highest value (more yellowish) was determined in the Advance cultivar, then followed by the HY37, BRSena and AP533 cultivars, and the lowest value in fruits from H9553 cultivar, then followed by H9992 and HY26 cultivars. The digital images taken through CieLab showed its highest values for chrome $b^{*}$ in the N901, IT761, Advance, BRSena, AP533 and U2006 cultivars. And through HunterLab, the highest values were found in the HY37, BRSena, IT761, U2006 and N901 cultivars, and both the lowest value was seen in Cultivar H9992.

Chrome $\mathrm{a}^{\star}$ and chrome $\mathrm{b}^{\star}$ from the tomatoes presented positive values, that is to say, reddish and yellowish tones, due to the present pigmentation, Lycopene and $\beta$-carotene, respectively. However, it was determined that the intensity of the red component (chrome $\mathrm{a}^{*}$ ) was higher than the yellow component (chrome $b^{*}$ ), due to the fact that the fruits were in its ripe and red stage (Tables 3 and 4). As well as for the luminosity, the tendency of chrome $b^{\star}$ is to decrease with the ripening, and this can be related to the fact that the lycopene can reach its highest concentration (Messina et al., 2012).

By using the transformed mathematics for the luminosity and chrome $\mathrm{a}^{*}$, no correlation was seen between the instrumental method and the utilization of digital images. Nevertheless, positive correlations were seen for chrome $b^{*}$ from the instrumental and image methods, mainly when using the space HunterLab with the logarithm, arc sine and square root transformed, and the space ColorLab with logarithm, arc tangent and square root transformed. Mendoza et al. (2006), observed a significant correlation between the colorimetric and image methods when working with the bananas, and concluded that the image methods seemed to be a good tool to quantify in a fast, cheap and easy way in acquiring data; however the color results had to be interpreted with caution.

\subsection{Others physicochemical characteristics}

All the physicochemical characteristics varied significantly amongst the tomato cultivars $(\mathrm{p}<0.05)$. The total acidity varied from 3.38 to $4.61 \mathrm{~g}_{\text {acid }} 100 \mathrm{~g}^{-1}$ sample $($ Table 5).

Table 2. Luminosity (average \pm standard deviation) from ripe fruits of eleven tomato for processing cultivars (Solanum Lycopersicum), determined through of colorimetric and image methods (CieLab and HunterLab). Goiânia, GO, Brazil.

\begin{tabular}{|c|c|c|c|}
\hline \multirow[t]{2}{*}{ Cultivar } & \multirow{2}{*}{$\begin{array}{c}\text { Colorimetric method } \\
\text { Luminosity }\end{array}$} & \multicolumn{2}{|c|}{ Image methods } \\
\hline & & Luminosity by Cielab & Luminosity by HunterLab \\
\hline IT761 $^{(1)}$ & $34.9^{\mathrm{Cd}} \pm 1,11$ & $53.8^{\mathrm{Aa}} \pm 3,81$ & $46.7^{\mathrm{Ba}} \pm 3.43$ \\
\hline H9992 & $36.7^{\mathrm{Aab}} \pm 0.94$ & $42.9^{\mathrm{Ab}} \pm 9.50$ & $36.5^{\mathrm{Ab}} \pm 8.73$ \\
\hline H9553 & $34.6^{\text {Bde }} \pm 0.90$ & $49.1^{\mathrm{Aab}} \pm 7.22$ & $42.2^{\mathrm{ABba}} \pm 7.01$ \\
\hline AP533 & $33.4^{\mathrm{Ce}} \pm 2.70$ & $51.5^{\mathrm{Aab}} \pm 1.94$ & $44.4^{\mathrm{Bab}} \pm 1.92$ \\
\hline Advance & $34.6^{\mathrm{Cde}} \pm 2.10$ & $51.7^{\mathrm{Aab}} \pm 3.63$ & $44.8^{\mathrm{Bab}} \pm 3.61$ \\
\hline N901 & $35.3^{\mathrm{Cbcd}} \pm 1.23$ & $51.9^{\mathrm{Aab}} \pm 3,84$ & $44.9^{\mathrm{Bab}} \pm 3,84$ \\
\hline BRSena & $35.3^{\mathrm{Ccd}} \pm 1.83$ & $54.4^{\mathrm{Aa}} \pm 4.02$ & $47.4^{\mathrm{Ba}} \pm 4.00$ \\
\hline U2006 & $36.5^{\mathrm{Babc}} \pm 2.35$ & $51.6^{\mathrm{Aab}} \pm 4.83$ & $45.5^{\mathrm{Aab}} \pm 4,03$ \\
\hline HY26 & $37.2^{\mathrm{Ca}} \pm 1.54$ & $51.5^{\mathrm{Aab}} \pm 2.54$ & $44.4^{\mathrm{Bab}} \pm 2.52$ \\
\hline HY37 & $34.2^{\mathrm{Cde}} \pm 1.64$ & $57.2^{\mathrm{Aa}} \pm 3.62$ & $50.2^{\mathrm{Ba}} \pm 3.71$ \\
\hline HY68 & $35.2^{\mathrm{Ccd}} \pm 1.62$ & $50.8^{\mathrm{Aab}} \pm 1.01$ & $43.7^{\mathrm{Bab}} \pm 1.04$ \\
\hline $\mathrm{CV}^{(2)}$ & 4.9 & 9.2 & 10.1 \\
\hline
\end{tabular}

${ }^{(1)}$ Average followed by different lower-case letters in the same column, and different capital letters on the same line differ from one another through the Turkey test ( $\mathrm{p}<0.05$ );

${ }^{(2)}$ Coefficient of variation (\%). 
Table 3. Chrome $\mathrm{a}^{*}$ (average \pm standard deviation) from the fruits of eleven tomato for processing cultivars (Solanum Lycopersicum), determined through of the colorimetric and image methods (CieLab and HunterLab). Goiânia, GO, Brazil.

\begin{tabular}{|c|c|c|c|}
\hline \multirow{2}{*}{ Cultivar } & \multirow{2}{*}{$\begin{array}{c}\text { Colorimetric method } \\
\text { Chrome }^{*}\end{array}$} & \multicolumn{2}{|c|}{ Image methods } \\
\hline & & Chrome $\mathrm{a}^{\star}$ by Cielab & Chrome $\mathrm{a}^{*}$ by HunterLab \\
\hline IT761 $^{(1)}$ & $25.3^{\mathrm{Bab}} \pm 1.44$ & $62.0^{\mathrm{Aabc}} \pm 4.4$ & $57.3^{\mathrm{Aab}} \pm 5.4$ \\
\hline H9992 & $23.7^{\mathrm{Ccd}} \pm 1.04$ & $56.1^{\mathrm{Acd}} \pm 4.4$ & $48.2^{\mathrm{Bcd}} \pm 6.2$ \\
\hline H9553 & $24.5^{\mathrm{Cbcd}} \pm 2.22$ & $57.2^{\mathrm{Abcd}} \pm 4.0$ & $50.7^{\mathrm{Bbcd}} \pm 3.6$ \\
\hline AP533 & $26.3^{\mathrm{Ca}} \pm 2.55$ & $60.8^{\mathrm{Aabc}} \pm 1.9$ & $55.2^{\mathrm{Babc}} \pm 2.3$ \\
\hline Advance & $25.3^{\mathrm{Cab}} \pm 1.66$ & $610^{\mathrm{Aabc}} \pm 3.3$ & $55.7^{\mathrm{Babc}} \pm 4.1$ \\
\hline N901 & $25.4^{\mathrm{Bab}} \pm 1.88$ & $65.4^{\mathrm{Aa}} \pm 3.4$ & $60.5^{\mathrm{Aa}} \pm 4.1$ \\
\hline BRSena & $24.7^{\mathrm{Cbc}} \pm 1.77$ & $56.2^{\mathrm{Abcd}} \pm 1.6$ & $51.3^{\mathrm{Bbcd}} \pm 1.9$ \\
\hline U2006 & $23.6^{\mathrm{Ccd}} \pm 1.08$ & $60.3^{\mathrm{Aabc}} \pm 2.5$ & $53.9^{\mathrm{Babc}} \pm 3.3$ \\
\hline HY26 & $23.0^{\mathrm{Cd}} \pm 1.43$ & $62.5^{\mathrm{Aab}} \pm 12$ & $56.2^{\mathrm{Bab}} \pm 1.1$ \\
\hline HY37 & $26.3^{\mathrm{Ca}} \pm 2.07$ & $51.0^{\mathrm{Ad}} \pm 2.1$ & $45.1^{\mathrm{Bd}} \pm 2.2$ \\
\hline HY68 & $25.2^{\mathrm{Cab}} \pm 1.58$ & $59.1^{\mathrm{Aabc}} \pm 1.0$ & $53.6^{\mathrm{Babc}} \pm 1.3$ \\
\hline $\mathrm{CV}^{(2)}$ & 7.9 & 5.0 & 6.8 \\
\hline
\end{tabular}

${ }^{(1)}$ Average followed by different lower-case letters in the same column, and capital letters on the same line differ from one another through the Turkey test $(\mathrm{p}<0.05)$; ${ }^{(2)}$ Coefficient of variation (\%).

Table 4. Chrome $\mathrm{b}^{\star}$ (average \pm standard deviation) from fruits of eleven tomato for processing cultivars (Solanum Lycopersicum), through the colorimetric method and image capitation methods (CieLab and HunterLab). Goiânia, GO, Brazil.

\begin{tabular}{|c|c|c|c|}
\hline \multirow{2}{*}{ Cultivar } & \multirow{2}{*}{$\frac{\text { Colorimetric method }}{\text { Chrome }^{*}}$} & \multicolumn{2}{|c|}{ Image methods } \\
\hline & & Chrome b*by Cielab & Chrome $b^{*}$ by HunterLab \\
\hline IT761 $^{(1)}$ & $21.7^{\mathrm{Cbc}} \pm 1.42$ & $61.6^{\mathrm{Aa}} \pm 2.2$ & $29.2^{\mathrm{Ba}} \pm 1.7$ \\
\hline H9992 & $19.5^{\mathrm{Bef}} \pm 1.32$ & $53.1^{\mathrm{Ab}} \pm 6.6$ & $23.0^{\mathrm{Bb}} \pm 5.1$ \\
\hline AP533 & $22.3^{\mathrm{Cabc}} \pm 1.69$ & $61.3^{\mathrm{Aa}} \pm 1.7$ & $28.1^{\mathrm{Bab}} \pm 1.1$ \\
\hline Advance & $25.6^{\mathrm{Ca}} \pm 2.53$ & $61.6^{\mathrm{Aa}} \pm 2.3$ & $28.2^{\mathrm{Bab}} \pm 2.0$ \\
\hline U2006 & $21.4^{\mathrm{Ccd}} \pm 2.46$ & $61.0^{\mathrm{Aa}} \pm 1.8$ & $28.7^{\mathrm{Ba}} \pm 2.0$ \\
\hline HY26 & $19.8^{\text {Cdef }} \pm 2.17$ & $59.1^{\mathrm{Aab}} \pm 1.3$ & $27.7^{\text {Bab }} \pm 1.0$ \\
\hline HY37 & $23.4^{\mathrm{Cab}} \pm 2.01$ & $59.3^{\mathrm{Aab}} \pm 5.4$ & $30.2^{\mathrm{Ba}} \pm 2.0$ \\
\hline HY68 & $21.4^{\mathrm{Ccd}} \pm 2.14$ & $59.4^{\mathrm{Aab}} \pm 1.3$ & $27.4^{\mathrm{Bab}} \pm 0.5$ \\
\hline $\mathrm{CV}^{(2)}$ & 9.0 & 5.6 & 8.9 \\
\hline
\end{tabular}

${ }^{(1)}$ Average followed by different lower case letters in the same column, and capital letters on the same line differ from one another through the Turkey test $(\mathrm{p}<0.05)$; ${ }^{(2)}$ Coefficient of variation (\%).

Table 5. Total acidity (TA), pH, total solid soluble (TSS) and the TSS/TA ratio of eleven tomato for processing cultivars (Solanum Lycopersicum). Goiânia, GO, Brazil.

\begin{tabular}{|c|c|c|c|c|}
\hline Cultivar & $\mathrm{AT}^{(1)}$ & $\mathrm{pH}$ & $\mathrm{SST}^{(2)}$ & SST/AT \\
\hline IT761 $1^{(3)}$ & $3.75^{\mathrm{b}} \pm 0.32$ & $4.48^{b} \pm 0.09$ & $4.44^{\mathrm{ab}} \pm 0.11$ & $1.18^{\mathrm{b}} \pm 0.09$ \\
\hline H9992 & $3.80^{\mathrm{b}} \pm 0.16$ & $4.44^{\mathrm{bc}} \pm 0.02$ & $4.53^{\mathrm{a}} \pm 0.61$ & $1.18^{\mathrm{b}} \pm 0.14$ \\
\hline H9553 & $3.80^{\mathrm{b}} \pm 0.13$ & $4.41^{\mathrm{bcd}} \pm 0.03$ & $3.72^{\mathrm{de}} \pm 0.12$ & $0.97^{\mathrm{cd}} \pm 0.04$ \\
\hline AP533 & $3.38^{c} \pm 0.16$ & $4.48^{\mathrm{b}} \pm 0.03$ & $4.45^{\mathrm{ab}} \pm 0.13$ & $1.31^{\mathrm{a}} \pm 0.07$ \\
\hline Advance & $3.75^{\mathrm{b}} \pm 0.21$ & $4.44^{\mathrm{bc}} \pm 0.05$ & $3.41^{\mathrm{e}} \pm 0.11$ & $0.91^{\mathrm{de}} \pm 0.06$ \\
\hline N901 & $4.61^{\mathrm{a}} \pm 0.21$ & $4.35^{\mathrm{d}} \pm 0.02$ & $4.01^{c d} \pm 0.13$ & $0.87^{\mathrm{de}} \pm 0.05$ \\
\hline BRSena & $3.45^{c} \pm 015$ & $4.67^{a} \pm 0.05$ & $4.66^{a} \pm 0.22$ & $1.35^{\mathrm{a}} \pm 0.08$ \\
\hline U2006 & $3.79^{b} \pm 0.14$ & $4.34^{\mathrm{d}} \pm 0.04$ & $4.13^{b c} \pm 0.19$ & $1.08^{\mathrm{bc}} \pm 0.07$ \\
\hline HY26 & $4.49^{\mathrm{a}} \pm 0.21$ & $4.35^{\mathrm{d}} \pm 0.07$ & $3.93^{\mathrm{cd}} \pm 020$ & $0.88^{\mathrm{de}} \pm 005$ \\
\hline HY37 & $4.60^{\mathrm{a}} \pm 0.18$ & $4.18^{\mathrm{e}} \pm 0.02$ & $3.89^{\mathrm{cd}} \pm 0.13$ & $0.85^{\mathrm{e}} \pm 0.05$ \\
\hline HY68 & $4.49^{\mathrm{a}} \pm 0,19$ & $4.38^{\mathrm{cd}} \pm 008$ & $4.10^{b c} \pm 0.23$ & $091^{\text {de }} \pm 0.07$ \\
\hline $\mathrm{CV}^{(4)}$ & 4.9 & 1.1 & 5.8 & 7.3 \\
\hline
\end{tabular}

\footnotetext{
${ }^{(1)} \mathrm{g}_{\text {acid }} 100 \mathrm{~g}^{-1}$ sample ${ }^{(2)}{ }^{(2)} \mathrm{Brix} ;{ }^{(3)}$ The average followed by different letters in the same column differ between each other when using the test Tukey $(\mathrm{p}<0.05)$; ${ }^{(4)}$ Coefficient of variation $(\%)$.
} 
The fruits of the N901, HY37, HY26 and HY68 cultivars presented higher values of total acidity (TA), AP533 and BRSena cultivars the lowest values, and the rest intermediary values (Table 5). Besides influencing the flavour of the fresh fruit and derivative products (concentrated pulp, tomato purée, ketchup and juices), the TA is related to energy saving during processing, which interferes with the thermal treatment timing during sterilisation. As the longer the AT is, the shorter will be the time and the better will be for the industry (Schwarz et al., 2013). These authors, working with the AP533 cultivar, found TA of $3.4 \mathrm{~g}_{\text {acid }} 100 \mathrm{~g}_{\text {sample }}^{-1}$, whilst Coimbra (2014) reported the TA of $3.3 \mathrm{~g}^{2}$ acid $100 \mathrm{~g}^{-1}$ sample for the same cultivar, values were very close to the ones that were found in this research.

The range of $\mathrm{pH}$ amongst the fruits of tomato cultivars for processing varied between 4.18 and 4.67 (Table 5). The BRSena cultivar presented the highest average $\mathrm{pH}$ followed by U2006, N901 and HY68 cultivars. The BRSena cultivar showed pH higher than the ideal level, the rest of the cultivars presented the average that fell within the range that was acceptable in tomato for processing, less than 4.5 and higher than 3.7 (Giordano et al., 2000 ). When the $\mathrm{pH}$ is lower than 4.5 , it prevents microorganisms from growing, whilst when the $\mathrm{pH}$ is higher than 4.5 , it requires longer time to sterilise the concentrated tomato pulp, which leads to a higher cost in energy consumption during processing (Monteiro et al., 2008).

The $\mathrm{pH}$ and TA correlated negatively $(-0,75 ; \mathrm{p}<0.05)$, predictably, the $\mathrm{pH}$ increases once the acids are dissociated (Menezes et al., 2009). Schwarz et al. (2013) reported pH of 4.55 for the AP533 cultivar, whilst Coimbra (2014) obtained 4.4 for the same cultivar. In this research an intermediary value of 4.48 for the $\mathrm{pH}$ was determined, close to the values obtained by the authors before mentioned.

The average value of total soluble solids (TSS) varied between 3.41 to $4.66^{\circ} \mathrm{Brix}$ (Table 1). The BRSena, AP533, H9992 and IT761 cultivars presented the highest TSS values, and the Advance and H9553 cultivars the lowest TSS level. The TSS has implications for the industrial production, as the materials with higher levels demand less tomato in quantity in order to produce its derived products, which reduces the cost of processing, as sugars and the acids (main constituents of TSS) are also the major constituents of the dehydrated fruits (Shirahige et al., 2010). For each $1^{\circ}$ Brix more in the raw material, there is a $20 \%$ increase in the production of concentrated tomato pulp during the industrialization process (Giordano et al., 2000).

Besides the TA, the flavour of the fruit is mostly determined by its content of TSS as well as its volatile compounds (Sobreira et al., 2010). The variation in the level of solid soluble is expected in the fruit of different genotypes, as there are various factors that interfere, such as the capacity of importing assimilated photosynthetic.

The fruits presented TSS/TA ratio variation of $58.8 \%$ (Table 5): The cultivars BRSena and AP533 cultivars presented the highest values of TSS/TA ratio, then followed by the IT761, H9992 and U2006 cultivars, whilst the HY37, N901, HY26, HY68 and Advance cultivars presented the lowest values. The TSS/AT ratio correlated negatively with the TA $(-0.85 ; \mathrm{p}<0.01)$ and positively with $\mathrm{pH}$ and TSS $(0.79$ and 0,82 , respectively; $\mathrm{p}<0.01)$.
According to Ferreira et al. (2010), the tomato has a lower acidity and a subtle taste if the value of the TSS/TA ratio is high, which makes it more suitable for table usage, whilst lower values are related to TA and an astringent taste, which is more suitable for the industrial processing, as it is easier to be processed throughout all the operations leading to less energy consumption during the thermal treatment process, although it minimises industrial performance. Schwarz et al. (2013) reported between 1.23 and 0.98 of TSS/TA ratio, for the fruits of the cultivars AP533, whilst the same cultivar presented value of 1.31 in this research, which is slightly higher. Coimbra (2014), however, reported TSS/TA ratio values of 1.13 and 1.61, in different levels of fertilization, which shows a great influence of this parameter on the chemical composition of tomatoes for processing.

\section{Conclusion}

The mixture of hexane, acetone, and ethanol (2:1:1) is more efficient in the extraction of lycopene and $\beta$-carotene than acetone on its own. The methods of assessing the color through image presented higher levels of luminosity and chrome $\mathrm{a}^{*}$ and $\mathrm{b}^{*}$ than the instrumental method, given that the HunterLab is closer to the colorimeter method, than CieLab. The analysis through digital images indicates that the procedure is promising, practical and affordable, and it can be used as a good instrument for analysing tomato colors. From the industry point of view, the cultivars with higher values of STT, TA, lycopene and $\mathrm{a}^{*}$ and lower $\mathrm{pH}$ and $\mathrm{L}^{*}$ are better. However, in this study, there was not a cultivar with all these desired characteristics combined together. Considering that the level of TSS is fundamental to industrial performance, the IT761, BRSena, AP543, and H9992 cultivars stand out, moreover these cultivars have higher levels of lycopene and darker red color.

\section{References}

Amr, A. S., \& Hussein, D. S. (2013). Tomato pomace pigment: extraction and use as food colorant. Jordan Journal of Agricultural Sciences, 9(1), 72-85. http://dx.doi.org/10.12816/0001093.

Association of Official Analytical Chemists - AOAC. (2012). Official methods of analysis of AOAC (19th ed.). Gaitlerburg: AOAC International.

Coimbra, K. D. G. (2014). Desempenho agronômico e caracterização físico-química de tomateiro industrial cultivado com adubação organomineral e química (Tese de doutorado) - Programa de Pósgraduação em Agronomia, Universidade de Brasília, Brasília.

Cruz, A. C. F., Santos, R. P., Iarema, L., Fernandes, K. R. G., Kuki, K. N., Araújo, R. F., \& Otoni, W. C. (2008). Métodos comparativos na extração de pigmentos foliares de três híbridos de Bixa orellana $\mathrm{L}$. Revista Brasileira de Biociências, 5(2), 777-779.

Ferreira, S. M. R., Freitas, R. J. S., Karkle, E. N. L., Quadros, D. A., Tullio, L. T., \& Lima, J. J. (2010). Quality of tomatoes cultivated in the organic and conventional cropping systems. Food Science and Technology (Campinas), 30(1), 224-230. http://dx.doi.org/10.1590/ S0101-20612010000100033.

Garcia, E., \& Barrett, D. M. (2006). Assessing lycopene content in California processing tomatoes. Journal of Food Processing and Preservation, 30(1), 56-70. http://dx.doi.org/10.1111/j.1745-4549.2005.00047.x.

Georgé, S., Tourniaire, F., Gautier, H., Goupy, P., Rock, E., \& Caris-Veyrat, C. (2011). Changes in the contents of carotenoids, phenolic compounds and vitamin $\mathrm{C}$ during technical processing and lyophilisation of red 
and yellow tomatoes. Food Chemistry, 124(4), 1603-1611. http:// dx.doi.org/10.1016/j.foodchem.2010.08.024.

Giordano, L. B., Silva, J. B. C., \& Barbosa, V. (2000). Escolha de cultivares e plantio. In J. B. C. Silva \& Giordano L. B. (Ed.), Tomate para processamento industrial (168 p.). Brasília: Embrapa Comunicação para Transferência de Tecnologia.

International Commission on Illumination - CIE. (2014). The effect of spectral power distribution on lighting for urban and pedestrian areas. Vienna: CIE. Retrieved from http://www.cie.co.at/

Méndez, I. I., Vera, G. A. M., Chávez, S. J. L., \& Carrillo, R. J. C. (2011). Quality of fruits in Mexican tomato (Lycopersicon esculentum Mill.) landraces. Vitae, 18(1), 26-32.

Mendoza, F., Dejmek, P., \& Aguilera, J. M. (2006). Calibrated color measurements of agricultural foods using image analysis. Postharvest Biology and Technology, 41(3), 285-295. http://dx.doi.org/10.1016/j. postharvbio.2006.04.004.

Menezes, C. C., Borges, S. V., Cirillo, M. Â., Ferrua, F. Q., Oliveira, L. F., \& Mesquita, K. S. (2009). Physical and physicochemical characterisation of different formulations of guava preserve (Psidium guajava, L.) from Pedro Sato cultivar. Food Science and Technology (Campinas), 29(3), 618-625. http://dx.doi.org/10.1590/S0101-20612009000300025.

Messina, V., Domínguez, P. G., Sancho, A. M., Walsöe de Reca, N., Carrari, F., \& Grigioni, G. (2012). Tomato quality during short-term storage assessed by colour and electronic nose. International Journal of Electrochemistry, 2012(1), 1-7. http://dx.doi.org/10.1155/2012/687429.

Monteiro, C. S., Baldi, M. E., Miguel, P. T. P. S., \& Haracemiv, S. M. C. (2008). Nutritional quality the antioxidants of the tomato "Italian type”. Alimentos e Nutrição, 19(1), 25-31.

Raiola, A., Rigano, M. M., Calafiore, R., Frusciante, L., \& Barone, A. (2014). Enhancing the health-promoting effects of tomato fruit for biofortified food. Mediators of Inflammation, 2014(1), 1-16. http:// dx.doi.org/10.1155/2014/139873. PMid:24744504.

Revista Campo \& Negócios. (2014). Goiânia recebe a $7^{a}$ edição do Congresso Brasileiro de Tomate Industrial. Retrieved from http:// www.revistacampoenegocios.com.br/o-7o-congresso-brasileiro-detomate-industrial-e-o-principal-evento-da-area-no-pais/
Rotino, G. L., Acciarri, N., Sabatini, E., Mennella, G., Scalzo, R. L., Maestrelli, B., Pandolfini, T., Scalzo, J., Mezzetti, B., \& Spena, A. (2005). Open field trial of genetically modified parthenocarpic tomato: seedlessness and fruit quality. BMC Biotechnology, 5(1), 32-40. http://dx.doi.org/10.1186/1472-6750-5-32. PMid:16371162.

Schwarz, K., Resende, J. T. V., Preczenhak, A. P., Paula, J. T., Faria, M. V., \& Dias, D. M. (2013). Agronomic performance and physicochemical quality in tomato hybrids grown without guiding. Horticultura Brasileira, 31(3), 410-418. http://dx.doi.org/10.1590/ S0102-05362013000300011.

Shirahige, F. H., Melo, A. M. T., Purquerio, L. F. V., Carvalho, C. R. L., \& Melo, P. C. T. (2010). Yield and fruit quality of Santa Cruz and Italian tomatoes depending on fruit thinning. Horticultura Brasileira, 28(3), 292-298. http://dx.doi.org/10.1590/S010205362010000300009.

Sobreira, F. M., Sobreira, F. M., Almeida, G. D., Coelho, R. I., Rodrigues, R., Matta, F. P. (2010). Taste quality of salad and cherry tomatoes and their relationship with the morphoagronomic characteristics of the fruits. Ciência e Agrotecnologia, 34(4), 1015-1023. http://dx.doi. org/10.1590/S1413-70542010000400031.

The World Processing Tomato Council. (2015). World production estimate as of 18 February 2015. Retrieved from http://www.wptc. to/releases-wptc.php

Van Dalen, G., Osman, F., \& Don, A. (2010). Colour and apperance analysis of fruit and vegetable soup using a digital colour imaging sistem. In Conference on Colour in Graphics, Imaging and Vison. Joensuu: Society for Imaging Science and Tecnology (pp. 399-406). Retrieved from http://www.ingentaconnect.com/contentone/ist/ cgiv/2010/00002010/00000001/art00063

Wu, D., \& Sun, D. W. (2013). Colour measurements by computer vision for food quality control-a review. Trends in Food Science \& Technology, 29(1), 5-20. http://dx.doi.org/10.1016/j.tifs.2012.08.004.

Wu, Z., Sun, S., Wang, F., \& Guo, D. (2011). Establishment of regeneration and transformation system of Lycopersicon esculentum microtom. British Biotechnology Journal, 1(3), 53-60. http://dx.doi.org/10.9734/ $\mathrm{BBJ} / 2011 / 356$. 